\title{
Minimum Wage Effects Throughout the Wage Distribution: Evidence from Brazil's Formal and Informal Sectors *
}

\author{
Pablo Fajnzylber ${ }^{* *}$
}

Área de classificação da ANPEC: Área 06 - Trabalho e Economia Demográfica. JEL No. J23, J31, J38.

Keywords: minimum wages, informal sector.

Palavras Chave: salário mínimo, setor informal.

\section{Abstract:}

This paper investigates the effects of minimum wages on the income and employment of individuals, using longitudinal data from Brazil's Monthly Employment Survey over the 1982-1997 period. We use information on 541,194 individuals aged 15 to 65, for which we consider data from two interviews performed 12 months apart. Our sample includes formal salaried workers (62\%), informal salaried (20\%) and self-employed (18\%). We provide detailed estimates of minimum wage effects at different points of the complete wage distribution, and calculate both contemporaneous and lagged effects, for formal and informal workers. In order to provide some insight into the potential effects of minimum wages on family welfare and poverty, we obtain separate estimates for men and women, for workers under and above age 21, and for household heads and non-heads. We find significant minimum wage effects across the whole wage distribution, and both in the formal and the informal sectors. We also find that the total impact of minimum wages on workers earnings (derived from current and lagged effects) is positive but smaller than the contemporaneous one. As for employment elasticities, our estimates suggest that they are negative for most low-wage workers, being lower in absolute value for formal salaried workers (around 0.1 at the bottom of the wage distribution) than for low-wage informal salaried and self employed (between -0.25 and -0.35 ). Other results include higher earnings elasticities for men, adults and heads of households than for women, teenagers and non-heads, respectively.

\section{Resumo:}

O artigo investiga os efeitos do salário mínimo sobre os rendimentos e o emprego de individuos, usando dados longitudinais da Pesquisa Mensal de Emprego do período 1982-1997. São utilizadas informações de 541.194 indivíduos de 15 a 65 anos, extraídas de duas entrevistas realizadas com um intervalo de 12 meses. Consideramos individuos inicialmente empregados seja como assalariados com carteira (62\%) ou sem carteira assinada (20\%), seja como conta proprias (18\%). Fornecemos estimativas detalhadas dos impactos do salário mínimo em diferentes puntos da distribuição de rendimentos e calculamos tanto efeitos contemporaneos quanto defasados. Também realizamos estimativas separadas, por sexo, idade e posição na família. Encontramos impactos significativos do salário mínimo sobre os rendimentos individuais ao longo de toda a distribuição de rendimentos, e tanto no setor formal quanto no informal. Os impactos combinados dos efeitos contemporaneos e defasados são positivos mas menores que os primeiros. As estimativas obtidas para as elasticidades-emprego são negativas e mostram-se menores em valor absoluto para os trabalhadores formais (cerca de -0.1 na base da distribuição) que para os informais (entre -0.25 e -0.35 para trabalhadores sem carteira e conta proprias, respectivamente). Outros resultados incluem maiores elasticidades de rendimentos para homens, adultos e chefes de família.

\footnotetext{
* I am grateful to William Maloney for valuable comments and suggestions, to Ana Maria Oliveira for her generous help in understanding the documentation of the Brazilian Monthly Employment Survey, and to Ari Francisco de Araujo Jr. for excellent research assistance. All views and any errors or omissions are the sole responsibility of the author.

${ }^{* *}$ Departamento de Economia e CEDEPLAR, Universidade Federal de Minas Gerais. Rua Curitiba, 832, $9^{\circ}$ andar. Belo Horizonte, MG, 30170 120, Brazil. Tel (55 31) 327991 62. Email: pablo@ cedeplar.ufmg.br.
} 


\section{Introduction}

In Brazil, as in other countries, the goal of the minimum wage legislation is to redistribute earnings to low-paid workers in order to assure the satisfaction of their basic needs. ${ }^{1}$ Determining the level of the minimum wage that best accomplishes this goal is not, however, an easy task, as there are a number of trade-offs and indirect effects involved.

The main emphasis in the academic literature has been on the potential of minimum wage increases to produce deleterious effects on the very poor workers they are intended to benefit. In particular, in a competitive setting positive wage effects could be compensated by possible negative impacts on employment. Indeed, higher minimum wages would lead employers to move back along their labor demand curves, causing a reduction in employment opportunities for low-skilled workers, particularly those for which the new minimum wage is binding. ${ }^{2}$ As a consequence, one should expect an increase in the flow of workers from the formal, protected sector of the labor market, towards unemployment, inactivity or informal jobs.

In developing countries with large informal sectors - such as Brazil - the latter effects are of particular concern. If minimum wages induce migration of workers from the formal to the informal sector, the corresponding increase in the supply of labor in the informal sector could, in principle, lower informal wages. There are, however, several countering effects that could lead to the opposite result (an increase in informal wages). First, the enlarged attractiveness of the formal sector after a minimum wage increase could lead more informal workers - and individuals out of the labor force - to look for jobs in the formal sector. ${ }^{3}$ Second, employers could choose to respond to higher minimum wages by substituting away from registered towards unregistered informal workers. ${ }^{4}$ Finally, there is considerable evidence that, at least in Brazil, minimum wages have been used as a numeraire not only in the protected formal sector of the labor market but also in the informal sector. ${ }^{5}$ This could account for increases in informal wages even in the context of an increasing supply of informal workers.

Although direct impacts of changes in the minimum wage should be expected to be largest on workers for whom the minimum is binding - e.g. workers whose earnings are in between the initial and the final level of the minimum wage - there are reasons to expect effects also outside this at-risk group,

\footnotetext{
${ }^{1}$ See Foguel, Carneiro and Ramos (2000) for an account of the evolution of the Brazilian minimum wage legislation.

${ }^{2}$ There is considerable controversy about the size of the disemployment effects of minimum wages. The early research, mostly based on time-series, generated relatively small negative estimates, in general between -0.1 and -0.2 (Brown, Gilroy and Kohen, 1982). The more recent work has adopted a cross-sectional perspective with results varying from non-significant or even marginally positive employment elasticities (Card and Krueger, 1994; Machin and Manning 1994) to estimates between 0.4 and -1.6 for people directly affected by minimum wage changes (Currie and Fallick 1993; Abowd, Kramarz and Margolis, 1999).

${ }^{3}$ As shown formally by Mincer (1976), when turnover rates are high relative to the elasticity of formal labor demand, a minimum wage hike may lead to a net flow of workers from the informal to the formal sector, and from inactivity into the labor force, as well as to an increase in informal wages and a reduction in informal employment. In Mincer's model, informal wages are equated to expected formal wages. It is worth noting, however, that because of unobservable intrinsic attributes of both formal and informal jobs, the corresponding expected wages in both sectors should not necessarily be equal in equilibrium. This is a plausible possibility if one adopts the view that the informal sector is not just the residual fraction of a dualistic labor market, but rather a potentially desirable destination for workers that choose between formality and informality on the basis of a rational cost-benefit analysis (Maloney, 1999).

${ }^{4}$ Needless to say, this is not a completely desirable outcome as it amounts to non-compliance with the minimum wage legislation, and would abate positive wage effects in the formal sector. However, as argued by Freeman (1996), in some circumstances, firms and employees may find it in their best interest not to comply with the minimum wage legislation.

${ }^{5}$ Neri (1997) shows that the fraction of workers that experienced wage increases identical to those in the minimum wage was, at least in the 1990s, larger for unregistered than for registered workers. Neri, Gonzaga and Camargo (2000) find that the percentage of workers that earn exactly one minimum wage is larger for informal (unregistered) workers (15\% in 1996) than for the formal salaried (8\%). The proportion of workers earning multiples of the minimum wage $(0.5,1,1.5,2$ or 3$)$ is also larger for informal $(20 \%)$ than for formal workers $(14 \%)$. Although to a smaller extent, even the self-employed show up as using minimum wages as some sort of numeraire: $8 \%$ earn multiples of the minimum wage.
} 
and possibly throughout the wage distribution. First, if the use of the minimum wage as a unit of account is a generalized practice in the labor market - the so-called numeraire effects - not only low-wage informal workers but also workers earning above the minimum, in both the formal and the informal sector, should be impacted. Secondly, in a competitive setting one should expect employers to respond to minimum wage increases by substituting away from workers whose productivity is valued below the new minimum. This would have the effect of increasing the demand for workers whose initial earnings and productivity were above the new minimum. ${ }^{6}$ Still, this effect could be partially compensated if the heightened attractiveness of formal (and possibly informal) employment leads to increased rates of participation in the labor force - that is to larger flows of individuals out of school or homekeeping activities into employment or unemployment.

One important question related to minimum wage effects has to do with the different timings with which the several above-mentioned effects operate. For instance, adjustments in wages could be expected to occur faster than employment effects, as firms take time to adjust the composition of their labor force. Voluntary transitions of individuals from inactivity towards the formal or the informal sectors, or from informality to formality, could also take more time to process themselves than do wage adjustments that follow legal or contractual obligations. As a consequence, one should not expect minimum wage effects to die out in a short period of time.

In theory, lagged effects could either amplify or abate the initial impacts of changes in minimum wages, depending on the individuals' position in the labor market and in the wage distribution. For instance, if the employment effects related to firms' responses to changes in relative labor costs are slower than direct wage effects, then the lagged impact of minimum wage increases would be favorable to workers earning above the minimum but negative for those making less than the minimum. If, however, the use of the minimum wage as a numeraire is a widespread phenomenon, one could expect minimum wage increases to have inflationary effects that after some time could lead to real reductions in the earnings of all workers. ${ }^{7}$ In this case, income effects for most workers would initially overshoot.

Given that the objective of the minimum wage policy is that of redistributing earnings towards low-income families, one important issue has to do with the differential impact that minimum wages can have, according to personal characteristics, such as gender, age and status in the family (heads/nonheads). ${ }^{8}$ Those differences could arise from distinct labor supply behavior across those groups, reflected in the nature of the work relationship (e.g. temporary as opposed to stable), the extent of part-time work and the degree of attachment to the labor force. Moreover, if in normal conditions employers may discriminate against some types of workers - e.g. women - one could expect the same behavior in the context of adjustments to minimum wage increases.

Because contributions to family income vary considerably by age, gender, and family status, differential responses to minimum wages across these groups are important to assess the impact of minimum wages on poverty. For instance, relatively larger income effects on heads of households would

\footnotetext{
${ }^{6}$ In the case of reductions of the minimum wage, a symmetric decrease in the demand for workers earning above the initial minimum should be expected, as the employment perspectives of those earning below the initial minimum are improved. Abowd et al. (1999) study periods of real increases and reductions in the minimum wage, respectively in France and the United States, and find that "[workers] employed between two real minima have much lower subsequent employment probabilities in France and much lower prior employment probabilities in the U.S." (p. 24).

${ }^{7}$ Freeman (1996) mentions the inflationary effects of minimum wages but implies that these effects are restricted to "minimum wage goods/services" and are proportional to the "minimum wage workers' share of the cost of production" (p. 640). The point here is that widespread numeraire effects that lead to wage increases throughout the wage distribution could lead to larger increases in prices of a wider spectrum of goods.

${ }^{8}$ Abowd et al. (1999) estimate minimum wage-employment elasticities that vary considerably by age and gender. Most of the literature on disemployment effects has focused on youth. In Europe, as reported by Dolado et al. (1996), the evidence suggests that effects are worse for this group than for adults. Neumark and Washer (1995) provide evidence of disemployment effects on American teenagers, especially those for which the minimum wage is binding.
} 
be a positive result in terms of the policy's goal of reducing poverty, and small income effects on the young would be less harmful than on adults. ${ }^{9}$ As for women, it is often assumed that their earnings have a small impact on household income: this was one of the explicit motivations of the British government when it abolished the Wage Councils in 1993 (given that most minimum wage workers were women). It is not clear, however, that the above assumption has strong empirical support, as Machin and Manning (1996), for instance, quote British evidence against it.

A related question that arises in this context is the extent to which low-income workers come from poor families. ${ }^{10}$ In Brazil, as in other countries, women, young and non-head-of-household individuals are over-represented at the bottom of the wage distribution, where the beneficial effects of minimum wages are arguably concentrated. If the earnings of those workers are not an important component of family income, one could make the case that possible beneficial effects of minimum wages on low-income workers do not necessarily translate into proportional increases in the income of poor families. Moreover, heads of households leaving in extreme poverty are often unemployed and are thus shielded from most beneficial effects of minimum wages.

Given that the goal of the minimum wage policy is, in a nutshell, that of reducing poverty, one could argue that a relevant test of its effectiveness should be based on its impact on household income. This is not, however, the approach adopted in this paper. Rather, our more limited objective is that of estimating the effects of minimum wages on the income and employment of individuals, using longitudinal data from Brazil's Monthly Employment Survey over the 1982-1997 period. Differently from previous research on minimum wage impacts in Brazil, we do not restrict the analysis to individuals earning one minimum or less, or to those earning multiples of the minimum. Instead, we follow Neumark, Schweitzer and Washer (2000) in providing detailed estimates of minimum wage effects at different points of the complete wage distribution, and calculate both contemporaneous and lagged effects. Given the importance of the informal sector in the Brazilian labor market, we provide estimates for both formal and informal salaried workers, and for self-employed individuals. We also estimate the impact of minimum wages on the probability of transitioning into different sectors of the labor market: out of salaried formal and informal work, and self-employment, and into unemployment and inactivity. Finally, in order to provide some insight into the potential effects of minimum wages on family welfare and poverty, we obtain separate estimates for men and women, for workers under and above age 21 , and for household heads and non-heads.

The rest of the paper is structured as follows. The second section presents the data and methodology and the third section reports estimation results. The final section summarizes our main findings and offers concluding remarks.

\section{Data and Methodology}

The Monthly Employment Survey (Pesquisa Mensal de Emprego or PME) is a periodical survey of households aimed at providing monthly employment indicators. It has been performed by Brazil's statistical agency (IBGE) since 1980, covering the metropolitan areas of São Paulo, Rio de Janeiro, Belo Horizonte, Porto Alegre, Recife and Salvador. ${ }^{11}$ One important advantage of the PME, compared to any

\footnotetext{
9 As put by Neumark, Schweitzer and Washer (2000), “[young workers] are likely to 'grow out' of minimum wages, [whereas] adults working at minimum wage jobs are more likely to be 'permanent' low wage workers" (p.12).

${ }^{10}$ Johnson and Browning (1983) show that in 1976 low-wage workers in the U.S. were evenly distributed across the household income distribution. Machin and Manning (1996) show that in the U.K. this distribution is more skewed towards poor households but a considerable fraction of low-wage workers pertains to relatively rich households. Dolado et al. (1996) present similar evidence for France, the Netherlands and Spain. In France and the U.K. more than 30\% of those at the bottom of the wage distribution pertain to families at the top $50 \%$ of the household income distribution.

${ }^{11}$ For descriptions of the methodology of the Pesquisa Mensal de Emprego, see Sedlacek, Barros and Varandas (1990), IBGE (1991), Bivar (1993) and Oliveira (1999).
} 
other household survey available in Brazil, is that it is designed as a rotating panel, so one can perform longitudinal comparisons across individuals. Each household is surveyed 4 consecutive months and is then dropped from the sample for 8 months, after which it is reintroduced for another 4 months. The rotation procedure is such that each month one fourth of the sample is substituted by households from a new panel. Thus, after 4 months the whole initial sample has been rotated and after 8 months a third different sample is being surveyed. After 12 months the initial sample is reencountered. Over a period of two years, three different panels of households are surveyed, and the process starts again with three new panels.

In this paper, we use a data set that we constructed from 22 different panels surveyed in the months of January, May and September, between 1982 and $1997 .{ }^{12}$ The final sample includes information on 541,194 individuals, for which we consider data from two interviews performed 12 months apart. The sample is restricted to individuals aged 15 to 65 in the first interview, that were (initially) employed as formal salaried workers (62\% of our sample), informal salaried (20\%) or self-employed (18\%). We excluded those individuals whose activities in the second interview were unknown, as well as those that had become unpaid workers or retirees. ${ }^{13}$ The matching of individuals across interviews was performed on the basis of household identification numbers, date of birth, gender and years of schooling. ${ }^{14}$ All employed individuals with missing earnings information were dropped, as were those that experienced yearly changes in real earnings of more than $1000 \%$. The resulting data set was merged with information on minimum wages and consumer price indexes, which were used as deflators. ${ }^{15}$ The sample was then restricted to individuals earning between 0.5 and 40 minimum wages.

As in Neumark et al. (2000), we estimate the impact of changes in real minimum wages $(\mathrm{mw})$ on changes in real monthly earnings $(w)$, allowing for different effects throughout the wage distribution and for lagged effects. We control for personal characteristics $(X)$, as well as for month $(M)$, period $(P)$ and metropolitan area $(S)$ effects. Since Brazil has a unique federal minimum wage policy since May 1984, the identification of the impact of the minimum wage comes mostly from its temporal variation. However, we also exploit, up to that month, the state-level variation in minimum wages. ${ }^{16}$ Our basic specification is as follows:

$$
\begin{aligned}
\frac{w_{i 2}-w_{i 1}}{w_{i 1}}= & \alpha+\sum_{j} \beta_{j}\left[\frac{m w_{2}-m w_{1}}{m w_{1}}\right] \cdot R\left(w_{i 1}, m w_{1}\right)_{j}+\sum_{j} \beta_{j}^{L}\left[\frac{m w_{1}-m w_{0}}{m w_{0}}\right] \cdot R\left(w_{i 1}, m w_{1}\right)_{j} \\
& +\sum_{j} \gamma_{j} R\left(w_{i 1}, m w_{1}\right)_{j}+\sum_{j} \phi_{j} R\left(w_{i 1}, m w_{1}\right)_{j}\left[\frac{w_{i 1}}{m w_{1}}\right]+X_{i 1} \delta+M_{i} \lambda+S_{i} P_{i} \pi+\varepsilon_{i}
\end{aligned}
$$

\footnotetext{
${ }^{12}$ We have attempted to cover all panels surveyed between May 1982 and May 1997. The dates of the (initial) interviews are as follows: May and September of 1982, 1984, 1986, 1988, 1990, 1992 and 1994; January of 1983, 1985, 1987, 1989, 1991, 1994 and 1996; May of 1996.

${ }^{13}$ The reason for excluding the retirees is that we ignore the value of the corresponding pensions. We did, however, keep the workers that in the second period had become unemployed, students, or homekeepers, and assumed that they had zero earnings. ${ }^{14}$ We only kept the individuals that experienced no change in their years of schooling across interviews, and those that experienced a one year increase and were enrolled in school at the time of either the first or the second interview.

${ }^{15}$ The earnings information provided in the Pesquisa Mensal de Emprego is referred to the month previous to the interview. We thus used minimum wages and price indexes corresponding to those months. As deflator, we used IBGE's Índice Nacional de Preços ao Consumidor Geral. As in Ferreira and Barros (1999), we applied the now standard procedure of upwardly adjusting that index by 1.2199 , starting in July 1994, to account for the actual price increases that took place in June of 1994 and were not computed into July's index. All real values mentioned in the paper are expressed in May 1997 reais. The source of the minimum wage series is Brazil's Labor Ministry and, for the series of Recife and Salvador up to April 1984, Foguel (1998).

${ }^{16}$ In practice, the 6 metro areas covered by the PME can be divided in two groups with common minimum wages between 1981 and 1984. Over this period, minimum wages in Recife and Salvador were on average 14\% lower than those in the other 4 metro areas. However, these differences declined over time - from being $17 \%$ below the cities in the southeast to $12 \%$ below at the end of the period.
} 
The subscript $i$ is referred to the individual, and the subscripts 0,1 and 2 denote observations from a year before the first interview, and from the first and second interviews respectively (hereafter "years 0,1 and 2"). For sake of notation simplicity we do not include subscripts for metro area, year and month.

In order to allow for different impacts of minimum wage changes across the distribution of wages, both the current and the lagged rates of growth of the minimum are interacted with a set of dummy variables $R_{j}$ that describe different positions in the wage distribution. We use 13 such $R_{j}$ variables, defined as of year 1 on the basis of the individual's wage relative to the minimum wage. ${ }^{17}$ Thus, for example, $R 1$ refers to individuals whose earnings are 0.9 minimum wages or less, $R 2$ refers to those earning between 0.9 and 1.1 minima, etc. (see table 1 for details on the ranges' definitions).

The $R_{j}$ variables are also included freestanding (omitting the dummy for the highest wage range) and as interactions with the ratio of the individual's wage to the minimum wage (as of year 1). These variables capture, respectively, different rates of change in wages across the wage distribution - for reasons unrelated to minimum wages - and different rates of change of wages within the ranges defined by the $R_{j}$ variables.

We control for the following personal characteristics (in $X$ ), defined as of year 1: gender, years of education $^{18}$, a dummy for individuals that completed an additional year of schooling between years 1 and 2 , experience and experience squared (both in year 1). We include month dummy variables $(M)$ for May and September (the excluded category being January) expecting to capture seasonal factors that could potentially influence wage growth. To control for the effects of varying macroeconomic conditions we include dummy variables $(P)$ defined as of year 1 for the following periods: 1982-83, 1984-86, 1987-89 and 1990-92 (1994-96 is the excluded period). These variables are interacted with metropolitan area dummies $(S)$ in order to control for the fact that the impact of macroeconomic shocks can vary across regions.

Our main interest resides in the estimated $\beta_{j}$ coefficients, which capture the percent contemporaneous change in earnings associated with a unit percent change in the minimum wage, for individuals whose wages relative to the minimum are positioned in the $j$ range (those for which the $R_{j}$ dummy is activated). We are also interested in long-run effects, although their calculation is not as simples as usual - e.g. summing up $\beta_{j}$ and $\beta^{L}$. This is because over time workers can change from one range to another, say from $j$ to $k$, so that the relevant parameters are in fact $\beta_{j}$ and $\beta^{L}{ }_{k}$. Thus, to calculate "total" effects one needs to predict the wage range of each worker a year after the initial change in the minimum, and consider the lagged effect for this new range. This procedure must also be followed for the counterfactual situation of no change in the minimum, since workers may experience significant wage growth (and range changes) even in the absence of minimum wage movements.

In practice, we first assume that no change in the minimum wage occurred between years 0 and 1 , and use the parameter estimates from equation (1) to predict wages in year 2 in each of two hypothesis regarding the change in the minimum between years 1 and 2: a 10\% increase and, for the counterfactual, no change in the minimum. These predicted wages are used to re-classify individuals in terms of their wages relative to the minimum, and new sets of $R j$ variables are defined (for both the cases of a $10 \%$ contemporaneous increase and of no change in the minimum). The new sets of predicted wages and $R j$ variables are then re-coded as if they were referent to period 1 (and not 2). Then, using these variables and assuming that there was no contemporaneous change in the minimum (between 1 and 2), we predict the

\footnotetext{
${ }^{17}$ If one had three years of data for each individual, a more flexible specification could be used, including also $R_{j}$ variables dependent on $\mathrm{w}_{\mathrm{i} 0}$ and $\mathrm{mw}_{0}$, and interacting the lagged rate of change of the minimum with these variables (instead of using $R_{j}$ variables defined as of year 1). As shown by Neumark et al. (2000), the adopted specification amounts to assuming that, conditioning upon the ratio of $\mathrm{w}_{\mathrm{i} 1}$ to $\mathrm{mw}_{1}$, "the individual's wage history does not matter"(p. 13). That is, the effect in year 2 of a change in the minimum that occurred between years 0 and 1 does not depend on the path of wages up to $\mathrm{w}_{1}$.

${ }^{18}$ We adopt a flexible specification, using one dummy variable for each number of years of schooling up to fourteen, a dummy for individuals with four or more years of under-graduate education, and a dummy for those with some graduate education (the excluded education category is "zero years of schooling").
} 
effect on earnings of, respectively, a lagged $10 \%$ increase and, for the counterfactual, no change in the lagged minimum (between 0 and 1). Total minimum wage effects are then calculated as the compounded change in wages after a contemporaneous and a lagged $10 \%$ increase in the minimum, minus the corresponding counterfactual compounded change in wages if the minimum had stayed constant in both years.

The described estimation procedure is applied to three categories of workers (as of year 1): formal salaried (employees registered with the Brazilian Labor Ministry), informal salaried (unregistered employees) and self-employed. In order to distinguish "pure" minimum wage effects on earnings from those that follow from employment effects, we consider, for each category of workers, four types of samples. First, we restrict ourselves to the workers that in year 2 remain in the same sector of the labor market than in year 1 (formal salaried, informal salaried or self-employed). We then include, sequentially, the workers that in year 2 were employed in a different sector of the labor market or had become employers, those that were unemployed, and those that were out of the labor force (in school or as homekeepers).

The comparison of the results obtained with these various types of samples provides indirect evidence on the impact that minimum wage changes can have on the flow of workers that transition between formality and informality, employment and unemployment, activity and inactivity.

\section{Results}

\section{Descriptive Statistics}

Tables 1 through 3 report descriptive statistics for workers that in year 1 were, respectively, formal salaried, informal salaried and self-employed. In each table, the left panel covers the workers that in year 2 remained in the same sector of the labor market as in year 1. The samples in the right panel also include workers that in year 2 had moved to another sector of the labor market, and those that had become unemployed or inactives (moving into school or homekeeping).

As expected, the fraction of the workforce that earns less than the minimum is much larger in the informal (informal salaried and self-employed) than in the formal sector - less than $1.5 \%$ in the latter vs. up to $15 \%$ in the former. The share of the workers whose earnings are close to the minimum is however much more similar across sectors - being largest for the informal salaried. This suggests that, as argued by Neri et al. (2000), the minimum wage does have a considerable influence on the wage setting process in the unprotected informal sector. Earnings in this sector are, however, systematically lower than in the informal sector, particularly in the self-employed segment.

Regarding the personal characteristics of workers across the wage distribution, it is clear that in the three segments of the labor market, education, age, and the proportions of men and household heads increase monotonically with individuals' wages relative to the minimum. The rate of change in earnings (between years 1 and 2), however, has a negative monotonic relation with individuals' earnings. At the bottom of the wage distribution, that rate is largest for formal salaried and smallest for informal salaried workers. Particularly in the samples in the left panels, year 2 earnings of workers in the lowest wage ranges are comparable to year 1 earnings of workers located in the immediately higher wage range. To some extent, this suggests that some of the lowest paid workers may stay only temporarily at the very bottom of the wage distribution.

As for the comparison of the samples in the left and the right hand side panels, it appears that there's a somewhat larger proportion of women, young individuals and non-heads of households among the workers that switch employment status between years 1 and 2. However, among the individuals in the ranges at the bottom of the wage distribution, those that stay in their initial employment status are somewhat less educated than those that move into a new status.

It is also worth noting that some personal characteristics are clearly different across sectors of the labor market. For instance, somewhat surprisingly, informal salaried workers are more educated than their 
formal counterparts. Self-employed workers, however, have on average between two and three years of schooling less than the rest of the workers (although the difference is smaller at the bottom of the wage distribution). Since the self-employed are also considerably older (40.5 years old on average vs. 33.5 and 34.3 for formal and informal salaried respectively), their labor market experience is larger than that of salaried (formal or informal) workers by around 9 years. Workers aged less than 21 earning around one minimum wage are only $6 \%$ among the self-employed, but represent $23 \%$ and $34 \%$ of the formal and informal salaried, respectively. As for gender, the proportion of women is on average largest among the informal salaried, although this ordering is inverted at the bottom of the wage distribution. Finally, heads of household are most prevalent among the self-employed, and least frequent among the informal salaried.

\section{Formal Salaried Workers}

Estimates of $\beta_{j}$ and $\beta_{j}^{L}$ (equation 1) for formal salaried workers are reported in table 4 . The results in columns (1) and (1') correspond to the sample of individuals that worked as formal salaried in both years 1 and 2. The estimates suggest significant positive effects of minimum wages on workers' earnings across all the wage distribution. Impacts are largest at the bottom and decline monotonically as one goes up over that distribution. The estimated elasticities are as high as 1.43 for those below 0.9 minima (1.08 for those at or around the minimum) and as low as 0.39 for those making more than 40 minima.

The results reported in columns (2), (3) and (4) indicate somewhat lower effects, suggesting that minimum wages could lead to larger flows out of formal employment into other segments of the labor market (mainly towards informality), unemployment and inactivity. However, most of the estimated elasticities (for a given range of wages) are not significantly different from each other - they fall into each others' $95 \%$ confidence intervals. Only in column (4), when all the above mentioned possible year 2 employment status are considered simultaneously, and for the bottom wage ranges, the estimated elasticities are statistically lower than those in column (1). The implied employment elasticities are quite small, which is consistent with the early literature on the subject: for workers earning below 0.9 minimum wages and between 0.9 and 1.1 minima, a $10 \%$ minimum wage increase would reduce the probability of employment by, respectively, $1.6 \%$ and $0.9 \% .^{19}$

Except for the workers at the very bottom of the distribution, lagged income effects are negative and significant, which suggests that part of the initial gains derived from minimum wage increases are lost in the following year. ${ }^{20}$ Total effects of a $10 \%$ increase in the minimum are shown in figures 1 and 2 , respectively for the first and the second year (the first year results basically reproduce the estimates for the "current" period in table 4). Year 2 effects are uniformly lower than current effects, especially for workers located relatively high in the wage distribution. Indeed, up to 2 minimum wages, total effects are more than $55 \%$ of current effects; they are below $40 \%$ of initial effects for workers earning between 4 and 9 minima, and less than $20 \%$ above 9 minima.

As for total employment elasticities, derived from the comparison of total effects for the sample of individuals working in year 2 and the largest sample, they are smaller than current ones: -0.08 and -0.05 , respectively, for workers in the two bottom wage ranges. Thus, the second period impact on the employment of low-paid workers partially compensates initial disemployment effects, which is consistent with a lagged real decline in the minimum wage.

\footnotetext{
${ }^{19}$ We obtain these elasticities from the comparison of columns (2) and (4). Consider, for example, the bottom range: after a $10 \%$ minimum wage increase, $98.4 \%$ of workers experience an increase of $13.95 \%$ in their earnings and $1.6 \%$ loose their jobs so they experience a $100 \%$ reduction in earnings; the result is an average increase of $(98.4 * .1395)+(1.6 *-1)=12.13 \%$.

${ }^{20}$ It is worth noting that total effects can be lower than current effects even if the coefficient on lagged minimum wage growth is positive or non-significant for the corresponding wage range. This is because minimum wage hikes may lead workers to move to higher ranges, where "natural" wage growth (for reasons unrelated to minimum wages) is lower.
} 


\section{Informal Salaried Workers}

Although somewhat smaller than the corresponding elasticities for formal salaried workers, first year income elasticities for unregistered workers (table 5) are also uniformly positive and significant over the whole wage distribution, suggesting strong numeraire minimum wage effects also in the informal salaried sector. However, as seen in figures 3 and 4, both current and total income effects decline at a faster rate as one moves up along the wage distribution of informal salaried workers. Not surprisingly, total effects as a fraction of current effects are smaller than in the formal salaried sector, which indicates that in this unprotected sector a larger fraction of the initial wage increase is lost over the second year.

The current elasticities in columns (2) and (3) are somewhat larger although not statistically different from those in (1). The only exception is given by the workers earning less than 0.9 minima: in the sample that includes individuals that move into another sector of the labor market we find a $13.9 \%$ wage increase after a $10 \%$ minimum wage hike, compared to $11.8 \%$ for workers that stay as informal salaried in year 2 . This suggests that, for those workers, an increase in the minimum wage enlarges the probability of moving from informal salaried work to another sector of the labor market (mainly formal salaried employment and self employment) with, on average, a corresponding increase in earnings.

As before, the results in column (4) are significantly lower than in the previous columns, at least for workers earning up to 1.5 minima. The implied employment elasticities derived from the comparison of (2) and (4) are larger than for the formal salaried sector: respectively -0.35 and -0.25 for the two bottom wage ranges in the first year; -0.15 and -0.05 respectively in the second year. A possible interpretation for this somewhat puzzling result is that some informal salaried workers, motivated by the increased attractiveness of the formal sector, queue for jobs in the formal sector. Alternatively, one could think that after the minimum wage increase some non-head of household individuals are able to quit the labor market thanks to the increased earnings of other family members.

\section{Self-Employed Workers}

As shown in table 6, the self-employed are also benefited by minimum wage increases, with earnings elasticities that, in the case of individuals earning around one minimum and staying in their initial employment status are significantly larger (1.32) than for formal and informal salaried workers (respectively 1.08 and 1.03). Income effects are also significant for higher wage ranges, at least up to 5 minimum wages. Lagged effects, however, are significant only for a few wage ranges and even then they are positive. Thus, it does not surprise to find total effects that are quite close to current effects. ${ }^{21}$

The earnings elasticities derived from the samples that include workers that switched selfemployment for other jobs (column 2) and for unemployment (column 3) are not significantly different from those in column (1), where only the workers that are still self-employed in year 2 are covered. When workers that quit the labor market are added to the sample (column 4), however, earnings elasticities become significantly smaller, at least for the two wage ranges at the bottom of the distribution. In this case, the reported results suggest year 1 negative employment elasticities (respectively -0.34 and -0.29 ) that are comparable to those encountered for informal salaried workers, and total employment elasticities that are larger than those for formal and informal salaried workers ( -0.16 for both bottom ranges). As in the case of the informal salaried, these disemployment effects could be associated to either larger incentives to look for jobs in other segments of the labor market, or to a reduced need to work due to possible positive effects of the minimum hike on family income.

One notable difference between the self-employed results and those for the other types of workers is that although earnings elasticities tend to decline as one moves up in the wage distribution, that reduction is not monotonic. Thus, for example, the elasticities for those making between 4 and 5 minimum wages

\footnotetext{
${ }^{21}$ Because of space constraints we do not report total effects for self-employed workers. Results are available from the author on request.
} 
are larger than for workers who earn between 1.5 and 4 minima. One possible explanation for this is that at least some of the self-employed workers are benefited by the increased purchasing power of their clients - especially when the latter are minimum wage workers.

\section{Gender}

We have also estimated earnings elasticities separately for men and women, for the three segments of the labor market hereby considered. ${ }^{22}$ Among formal salaried workers, elasticities are larger for men than for women in most wage ranges - the only exceptions being workers earning between 3.5 and 5 minimum wages. When employment effects are not taken into account, these differences are statistically significant only between 1.1 and 2 minimum wages. However, when one uses the samples that includes workers that changed employment status, the difference between men and women elasticities is statistically significant for all ranges up to 3.5 minima. As for the differences between "pure" earnings elasticities and those derived from the larger samples, they are greater for women than for men, suggesting that among formal salaried workers disemployment effects are more important for women.

Similar results are encountered in the informal salaried sector, where women also display lower earning elasticities, especially at the bottom of the distribution and when disemployment effects are taken into account. Thus, for example, men earning around one minimum wage experience an $11.4 \%$ increase in earnings after a $10 \%$ increase in minimum wages, while the increase for women is only $5.9 \%$. Disemployment effects, derived from comparing elasticities between samples in which non-working individuals in year 2 are or not included, also suggest that the negative impact on women employment is much larger than for men. For workers earning below 0.9 minima or between 0.9 and 1.1 minima, a $10 \%$ increase in the minimum causes an employment reduction of, respectively $1.4 \%$ and $1.6 \%$ on men; for women the corresponding reductions are $4.8 \%$ and $3.0 \% .^{23}$ Among the self-employed, women are also disfavored in terms of their lower earnings elasticities, at least for workers earning up to 2.5 minima. Disemployment elasticities are also larger for women, especially at the bottom of the wage distribution: respectively -0.36 and -0.35 in the first two ranges, compared to -0.18 and -0.12 for men.

Age

We repeated the estimation for samples of workers aged 21 and older (“adults") and workers aged 15 to 20 years old ("teenagers"). In the case of formal salaried workers, minimum wage effects on earnings are significant across most of the wage distribution, for both teenagers and adults. However, earning elasticities are not significantly different from zero for informal salaried teenagers making more than 2.0 minimum wages, and for self-employed teenagers earning more than 1.1 minima. In general, teenagers are affected by minimum wages increases they are less favored than adults, as their earnings increase by a significantly smaller amount. This is true for formal salaried workers earning up to 2.5 minimum wages, for informal salaried making between 1.1 and 2.0 minima, and for self-employed workers earning between 0.9 and 1.1 minimum wages. ${ }^{24}$

As for employment elasticities, results are mixed across sectors of the labor market. At least at the bottom of the wage distribution (workers earning less than 1.1 minimum wages) formal salaried teenagers are more responsive to minimum wage increases than adults are. The same is true for informal salaried

\footnotetext{
${ }^{22}$ Also because of space constraints we do not report results by gender, age and household status. Results are available from the author on request.

23 It is worth noting that in the range below 0.9 minimum wages, the pure earnings elasticity for men (0.78) is significantly below that of women (1.34). However, these difference vanishes when one uses the sample that includes individuals that in year 2 are working in other sectors of the labor market (because of space limitations we do not report these results). It thus appears that after minimum wage hikes men at the very bottom of the wage distribution are more likely than women to move to better jobs.

${ }^{24}$ One exception worthy of note is given by the self-employed teenagers earning less than 0.9 minimum wages, whose income elasticity is larger than for their adult counterparts.
} 
teenagers earning less than 0.9 minima: in this range their employment elasticity is -0.38 compared to 0.08 for adults. However, for the self-employed the elasticities of employment with respect to minimum wages are larger in absolute value for adults, as they also are in the informal salaried sector for workers that earn around one minimum.

\section{Heads and Non-Heads of Household}

Overall, earnings elasticities are larger for heads than for non-heads of households, especially when disemployment effects are taken into account and for workers making up to 2.5 minimum wages. In the case of formal salaried workers, the larger effect on heads of households is also found for the sample of workers that stay in the same employment status in year 2. This, however, is not the case in the informal salaried and the self-employment sectors, in which the larger earnings elasticities for heads of households can be attributed to a larger responsiveness of employment to minimum wages. Indeed, employment elasticities are quite similar among the formal salaried, but in the other sectors they are larger in absolute value for non-heads of household. Among the informal salaried, for example, elasticities in the two bottom wage ranges are -0.37 and -0.24 for non-heads, compared to -0.16 and -0.19 for heads of household in the same wage ranges.

\section{Conclusions}

This paper has shown that the effects of minimum wages on monthly real earnings of Brazilian workers are not restricted to those earning around or below one minimum wage in the formal protected sector. Rather, significant minimum wage effects appear to be present across the whole wage distribution, and they seem to affect not only formal but also informal salaried, as well as self-employed workers.

Significant effects on workers with earnings above the minimum wage could be interpreted as the result of a change in the composition of the workforce of firms that substitute away from minimum wage workers. Moreover, the fact that these effects decline with earnings could be thought as the result of a declining degree of substitutability between minimum wage workers and other workers, as one goes up in the wage distribution. However, since sizeable minimum wage effects are present even very high in that distribution, and in the formal as well as in the informal sectors of the labor market, it is reasonable to think that another, complementary, explanation could be appropriate. Namely, our findings can be thought of as supportive evidence for the existence of so-called numeraire effects. Thus, even workers whose earnings are well above the minimum and workers in the informal sector could be setting their earnings in terms of minimum wages, which would then serve as a unit of account voluntary chosen by employers, employees and self-employed, especially at the bottom of the wage distribution.

We have also calculated total effects of minimum wage changes, which take into account not only current but also lagged effects. For most workers, we have found that total changes in workers' earnings are smaller than current ones, although total effects are still positive. Once again, we believe that two possible interpretations could apply to this finding. In the case of low-wage workers, earnings could overshoot after a minimum wage hike because after some time employers could substitute away from these workers. This would not explain, however, the fact that workers earning above the minimum are also affected adversely by lagged effects, as those workers should be benefited by the above mentioned changes in the mix of the workforce. An alternative interpretation could be that minimum wage hikes could have inflationary effects derived from the fact that, thanks to numeraire effects, not only low-wage workers but also most of the labor force would experience wage increases. Thus, inflation would erode part of the wage gains experienced by most workers, especially those with lower bargaining power which could explain our finding of lower total effects among the informal salaried and relatively larger total effects among the self-employed.

An additional finding of this paper is the existence of negative elasticities of employment with respect to minimum wages. We have derived those elasticities indirectly, by comparing earnings effects 
between samples of workers that stay employed and samples that also include workers that became unemployed or moved out of the labor force. Although our estimates are relatively low in the case of the formal salaried sector - around -0.1 at the bottom of the wage distribution - they are larger in absolute value for low-wage informal salaried and self employed (between -0.25 and -0.35 ). These results are consistent with informal workers moving into the formal sector because of its increased attractiveness after a minimum wage increase, or moving out of the labor force motivated either by lower employment prospects or by increases in household income brought about by the higher earnings of other family members.

Since the goal of the minimum wage policy is that of reducing poverty, the most relevant of its effects should be those on the individuals that are most likely to be primary wage earners of low-income families. However, as suggested by our data, individuals at the bottom of the Brazilian wage distribution - arguably the most affected by minimum wages - are more likely to be women, young and non-head of household. Thus, unless the responsiveness to minimum wage changes varies - in the "right" direction by gender, age and status in the household, minimum wage effects on low-wage individuals could overstate the corresponding effects on low-income households.

With this motivation, we have provided separate estimates for men and women, teenagers and adults, and heads and non-heads of household. Our results suggest that there are in fact considerable differences in earnings and employment elasticities across individuals with different demographic characteristics. Moreover, these differences are such that they minimize the possibility of income effects on low-wage individuals overstating income effects on poor households. Indeed, we find that the earnings of men and heads of households are more affected by minimum wages than those of women and nonheads, respectively. Also, we find negative employment elasticities that are larger in absolute value for the latter groups. These results apply to both the formal and the informal sectors. However, in the informal sector, most of the larger earnings effects for heads of household follow from the fact that they are less likely to change their employment status because of minimum wage changes than non-heads are. As for the results by age, we find that adults have larger earnings elasticities. In fact, in the informal sector the income of teenagers is only affected by minimum wages at the bottom of the wage distribution. The comparisons of employment elasticities by age provide mixed results. Teenagers are more affected than adults in the formal salaried sector and at the very bottom of the informal salaried sector (below 0.9 minimum wages), but they are less affected among the self-employed and among the informal salaried that earn around one minimum wage.

To conclude, it is worth noting that this paper has not provided a complete test of the effectiveness of the minimum wage policy regarding its potential to reduce poverty. To answer this question, one would have to produce direct estimates of the effects of minimum wages on household - rather than on individual - income. However, an alternative that could be pursued as an extension of the present paper is that of performing simulations of the effects of minimum wages on household income, by aggregating within each household the estimated effects on the earnings of individuals. Other extensions include the estimation of minimum wage effects on hours worked, as well as on hourly wages.

\section{References:}

Abowd, J. M., F. Kramarz and D. N. Margolis, 1999. "Minimun Wages and Employment in France and The United States.” National Bureau of Economic Research, Working Paper No. 6996.

Bivar, W. S. B. 1993. "Aspectos da Estrutura do Desemprego no Brasil: Composição por Sexo e Duração." $17^{\circ}$ Prêmio BNDES de Economia, Banco Nacional de Desenvolvimento Econômico e Social.

Brown, C., C. Gilroy and A. Kohen, 1982. "The Effect of Minimun Wage on Employment and Unemployment." Journal of Economic Literature 20 (2): 487-528. 
Card, D. and A. B. Krueger, 1994. "Minimun Wages and Employment: A Case Study of the Fast-Food Industry in New Jersey and Pennsylvania." American Economic Review 84(4): 772-793.

Currie, J. and B. Fallick, 1993. "A Note on the New Minimun Wage Research." National Bureau of Economic Research, Working Paper No. 4348.

Dolado, J. et all. 1996. “The Economic Impact of Minimun Wages in Europe.” Economic Policy 23: 317 372.

Ferreira, F. H. G. and R. P. de Barros, 1999. "The Slippery Slope: Explaining the Increase in Extreme Poverty in Urban Brazil, 1976-1996.” Revista Brasileira de Econometria 19 (2): 211-296.

Foguel, M. N. 1998. "Uma Avaliação dos Efeitos do Salário Mínimo sobre o Mercado de Trabalho no Brasil.” Instituto de Pesquisa Econômica e Aplicada, Texto para Discussão No. 564.

Foguel, M. N., F. G. Carneiro and L. Ramos, 2000. "The Economic Impact of Minimun Wages in Brazil”, mímeo.

Freeman, R. B. 1996. “The Minimun Wage as a Redistributive Tool.” The Economic Journal 106 (436): 639-649.

IBGE. 1991. "Para Compreender a PME."

Johnson, W. and E. Browning, 1983. "The Distribution and Efficiency Effects of Increasing the Minimun Wage: A Simulation.” American Economic Review 73: 204-211.

Machin, S. and A. Manning, 1994. "Minimun Wages, Wages Dispertion and Employment: Evidence from the UK Wage Councils." Industrial and Labour Relations Review 47: 319-329..

Machin, S. and A. Manning, 1996. "Employment and the Introduction of Minimun Wage in Britain." The Economic Journal 106 (436): 667-677.

Maloney, W. F. 1999. "Does Informality Imply Segmentation in Urban Labour Markets? Evidence from Sectoral Transitions in México." The World Bank Economic Review 13 (2): 275-302.

Mincer, J. 1976. "Unemployment Effects of Minimum Wages." Journal of Political Economy 84 (4-2): S87-S103.

Neri, M. 1997. “O Reajuste do Salário Mínimo de Maio de 1995.” Anais da Sociedade Brasileira de Econometria, Recife.

Neri, M., G. Gonzaga and J. M. Camargo, 2000. "Efeitos Informais do Salário Mínimo e Pobreza.” EPGE / FGV, Ensaios Econômicos No. 372.

Newmark, D., and W. Wascher, 1992. "Minimun-Wage Effects on School and Work Transitions of Teenagers." American Economic Review 85 (2): 244-249.

Newmark, D., M. Schweitzer and W. Wascher, 1995. "Minimun-Wage Effects on School and Work Transitions of Teenagers." American Economic Review 85 (2): 244-249.

Newmark, D., M. Schweitzer and W. Wascher, 2000. "The Effects of Minimun Wages throughout the Wage Distribution" National Bureau of Economic Research, Working Paper No. 7519.

Oliveira, A. M. H. C. 1999. "Relatório Metodológico: Microdados da Pesquisa Mensal de Emprego." CEDEPLAR / UFMG, mímeo.

Sedlacek, G., R. P de Barros and S. Varandas, 1990. "Segmentação e Mobilidade no Mercado de Trabalho: A Carteira de Trabalho em São Paulo.” Pesquisa e Planejamento Econômico 20 (1): 87 103. 
Table 1 - Descriptive Statistics for Samples of Registered Employees(*)

\begin{tabular}{|c|c|c|c|c|c|c|c|c|c|c|c|c|c|c|c|c|c|c|}
\hline \multicolumn{3}{|c|}{ Sample: Status in Year2 } & \multicolumn{5}{|c|}{ Working as Registered Employee } & \multirow[b]{2}{*}{$\begin{array}{c}\text { Age }<21 \\
(\%)\end{array}$} & \multirow[b]{2}{*}{$\begin{array}{c}\text { Heads } \\
(\%)\end{array}$} & \multicolumn{9}{|c|}{ Working, Unemployed or Inactive $\left({ }^{\star \star}\right)$} \\
\hline $\begin{array}{l}\text { Income / } \\
\text { Min. W. }\end{array}$ & $\begin{array}{l}\text { Sample } \\
\text { Fraction }\end{array}$ & N. Obs. & $\begin{array}{l}\text { Income } \\
\text { (Y1) }\end{array}$ & $\begin{array}{l}\text { Income } \\
\text { (Y2) }\end{array}$ & $\begin{array}{l}\text { Years of } \\
\text { School. }\end{array}$ & Age & $\begin{array}{c}\text { Women } \\
(\%)\end{array}$ & & & $\begin{array}{l}\text { Sample } \\
\text { Fraction }\end{array}$ & N. Obs. & $\begin{array}{c}\text { Income } \\
(Y 1)\end{array}$ & $\begin{array}{c}\text { Income } \\
\text { (Y2) }\end{array}$ & $\begin{array}{l}\text { Years of } \\
\text { School. }\end{array}$ & Age & $\begin{array}{c}\text { Women } \\
(\%)\end{array}$ & $\begin{array}{c}\text { Age }<21 \\
(\%)\end{array}$ & $\begin{array}{c}\text { Heads } \\
(\%)\end{array}$ \\
\hline$[0.5,0.9]$ & 0.013 & 3536 & 120.1 & 183.6 & 4.0 & 34.3 & 0.64 & 0.19 & 0.32 & 0.015 & 4989 & 119.3 & 154.8 & 4.2 & 33.4 & 0.64 & 0.22 & 0.30 \\
\hline$(0.9,1.1]$ & 0.112 & 31048 & 152.9 & 205.0 & 5.1 & 31.6 & 0.54 & 0.21 & 0.33 & 0.121 & 40961 & 151.5 & 178.8 & 5.2 & 31.1 & 0.55 & 0.23 & 0.31 \\
\hline$(1.1,1.5]$ & 0.102 & 28173 & 211.2 & 262.5 & 5.5 & 31.4 & 0.45 & 0.19 & 0.41 & 0.107 & 36135 & 209.9 & 231.5 & 5.5 & 31.0 & 0.46 & 0.20 & 0.39 \\
\hline$(1.5,2.0]$ & 0.130 & 36067 & 275.2 & 320.1 & 6.0 & 31.7 & 0.40 & 0.15 & 0.46 & 0.134 & 45197 & 272.8 & 286.7 & 6.0 & 31.4 & 0.41 & 0.16 & 0.44 \\
\hline$(2.0,2.5]$ & 0.104 & 28952 & 351.2 & 388.4 & 6.3 & 32.4 & 0.35 & 0.11 & 0.52 & 0.105 & 35601 & 348.1 & 353.0 & 6.4 & 32.2 & 0.36 & 0.12 & 0.50 \\
\hline$(2.5,3.0]$ & 0.078 & 21631 & 414.2 & 442.6 & 6.8 & 32.9 & 0.31 & 0.09 & 0.56 & 0.077 & 26122 & 410.6 & 408.2 & 6.8 & 32.9 & 0.32 & 0.09 & 0.55 \\
\hline$(3.0,3.5]$ & 0.067 & 18664 & 489.5 & 510.0 & 7.0 & 33.3 & 0.29 & 0.07 & 0.59 & 0.066 & 22386 & 484.4 & 472.7 & 7.1 & 33.2 & 0.30 & 0.08 & 0.58 \\
\hline$(3.5,4.0]$ & 0.056 & 15513 & 570.3 & 581.5 & 7.4 & 33.8 & 0.27 & 0.06 & 0.62 & 0.054 & 18386 & 565.6 & 546.3 & 7.5 & 33.8 & 0.28 & 0.06 & 0.61 \\
\hline$(4.0,5.0]$ & 0.082 & 22657 & 672.1 & 667.0 & 7.8 & 34.5 & 0.25 & 0.04 & 0.66 & 0.078 & 26499 & 666.5 & 630.7 & 7.9 & 34.4 & 0.26 & 0.04 & 0.64 \\
\hline$(5.0,6.0]$ & 0.050 & 13948 & 794.3 & 769.9 & 8.3 & 34.9 & 0.25 & 0.03 & 0.68 & 0.048 & 16214 & 786.8 & 730.5 & 8.4 & 34.9 & 0.27 & 0.03 & 0.66 \\
\hline$(6.0,9.0]$ & 0.089 & 24614 & 1068.4 & 1017.5 & 9.4 & 35.5 & 0.25 & 0.02 & 0.70 & 0.084 & 28363 & 1061.6 & 974.2 & 9.5 & 35.6 & 0.26 & 0.02 & 0.68 \\
\hline$(9.0,12]$ & 0.042 & 11741 & 1491.6 & 1397.6 & 10.7 & 36.2 & 0.23 & 0.01 & 0.73 & 0.040 & 13435 & 1478.2 & 1337.7 & 10.7 & 36.3 & 0.24 & 0.01 & 0.72 \\
\hline$(12,40]$ & 0.075 & 20736 & 2770.6 & 2434.6 & 12.5 & 38.1 & 0.18 & 0.00 & 0.81 & 0.069 & 23403 & 2750.0 & 2355.0 & 12.5 & 38.3 & 0.19 & 0.00 & 0.80 \\
\hline Full Sample & 1.000 & 277280 & 669.8 & 660.3 & 7.3 & 33.5 & 0.34 & 0.10 & 0.56 & 1.000 & 337691 & 639.1 & 599.8 & 7.3 & 33.2 & 0.36 & 0.11 & 0.53 \\
\hline
\end{tabular}

$\left({ }^{\star}\right)$ Sample means when not otherwise specified. $\left(^{\star *}\right)$ The income of unemployed and out-of-the-labor-force individuals is assumed to be zero. Inactive individuals include those in school and homekeepers. 
Table 2 - Descriptive Statistics for Samples of Un-Registered Employees(*)

\begin{tabular}{|c|c|c|c|c|c|c|c|c|c|c|c|c|c|c|c|c|c|c|}
\hline \multicolumn{3}{|c|}{ Sample: Status in Year2 } & \multicolumn{7}{|c|}{ Working as Un-Reqistered Emplovee } & \multicolumn{9}{|c|}{ Workinq, Unemploved or Inactive( $\left.{ }^{\star \star}\right)$} \\
\hline $\begin{array}{l}\text { Income / } \\
\text { Min. W. }\end{array}$ & $\begin{array}{l}\text { Sample } \\
\text { Fraction }\end{array}$ & N. Obs. & $\begin{array}{l}\text { Income } \\
\text { (Year 1) }\end{array}$ & $\begin{array}{l}\text { Income } \\
\text { (Year 2) }\end{array}$ & $\begin{array}{l}\text { Years of } \\
\text { School. }\end{array}$ & Age & $\begin{array}{c}\text { Women } \\
(\%)\end{array}$ & $\begin{array}{c}\text { Age }<21 \\
(\%)\end{array}$ & $\begin{array}{c}\text { Heads } \\
(\%)\end{array}$ & \begin{tabular}{|c|} 
Sample \\
Fraction
\end{tabular} & N. Obs. & $\begin{array}{l}\text { Income } \\
\text { (Year 1) }\end{array}$ & $\begin{array}{l}\text { Income } \\
\text { (Year 2) }\end{array}$ & $\begin{array}{l}\text { Years of } \\
\text { School. }\end{array}$ & Age & $\begin{array}{c}\text { Women } \\
(\%)\end{array}$ & $\begin{array}{c}\text { Age }<21 \\
(\%)\end{array}$ & $\begin{array}{c}\text { Heads } \\
(\%)\end{array}$ \\
\hline$\overline{0.5-0.9}$ & 0.113 & 6550 & 105.4 & 138.4 & 4.5 & 26.5 & 0.57 & 0.47 & 0.18 & 0.132 & 14091 & 105.5 & 123.1 & 4.7 & 26.8 & 0.59 & 0.44 & 0.18 \\
\hline $0.9-1.1$ & 0.126 & 7291 & 139.8 & 172.9 & 5.1 & 29.8 & 0.50 & 0.33 & 0.27 & 0.161 & 17262 & 140.2 & 157.3 & 5.4 & 28.9 & 0.53 & 0.34 & 0.24 \\
\hline $1.1-1.5$ & 0.095 & 5496 & 198.1 & 226.7 & 5.7 & 31.1 & 0.41 & 0.26 & 0.34 & 0.116 & 12367 & 197.6 & 214.0 & 5.7 & 30.1 & 0.42 & 0.27 & 0.32 \\
\hline $1.5-2.0$ & 0.098 & 5685 & 261.5 & 306.3 & 6.9 & 33.5 & 0.43 & 0.15 & 0.38 & 0.108 & 11578 & 256.6 & 279.4 & 6.6 & 32.3 & 0.41 & 0.18 & 0.39 \\
\hline $2.0-2.5$ & 0.078 & 4537 & 337.9 & 373.8 & 7.8 & 34.4 & 0.42 & 0.10 & 0.45 & 0.080 & 8607 & 333.0 & 350.9 & 7.3 & 33.5 & 0.39 & 0.13 & 0.45 \\
\hline $2.5-3.0$ & 0.064 & 3715 & 404.4 & 437.2 & 8.6 & 35.4 & 0.41 & 0.07 & 0.48 & 0.058 & 6180 & 396.6 & 415.8 & 8.1 & 34.9 & 0.40 & 0.08 & 0.49 \\
\hline $3.0-3.5$ & 0.058 & 3336 & 472.4 & 516.3 & 9.2 & 35.9 & 0.42 & 0.05 & 0.50 & 0.051 & 5471 & 462.5 & 485.9 & 8.7 & 35.2 & 0.39 & 0.06 & 0.51 \\
\hline $3.5-4.0$ & 0.053 & 3091 & 553.1 & 571.0 & 9.3 & 36.5 & 0.38 & 0.04 & 0.54 & 0.044 & 4752 & 546.8 & 552.6 & 8.9 & 36.2 & 0.37 & 0.05 & 0.55 \\
\hline $4.0-5.0$ & 0.074 & 4293 & 655.9 & 676.6 & 10.0 & 37.2 & 0.40 & 0.03 & 0.57 & 0.061 & 6546 & 649.3 & 653.2 & 9.6 & 36.9 & 0.38 & 0.03 & 0.57 \\
\hline $5.0-6.0$ & 0.049 & 2835 & 771.7 & 788.5 & 10.7 & 38.4 & 0.43 & 0.02 & 0.58 & 0.038 & 4060 & 762.7 & 759.0 & 10.4 & 38.0 & 0.41 & 0.02 & 0.58 \\
\hline $6.0-9.0$ & 0.088 & 5118 & 1033.6 & 982.7 & 11.4 & 38.7 & 0.40 & 0.01 & 0.62 & 0.069 & 7390 & 1027.3 & 962.4 & 11.1 & 38.5 & 0.38 & 0.01 & 0.62 \\
\hline $9.0-12$ & 0.040 & 2298 & 1413.2 & 1337.4 & 12.1 & 39.6 & 0.36 & 0.01 & 0.67 & 0.032 & 3440 & 1403.9 & 1285.4 & 11.9 & 39.4 & 0.35 & 0.01 & 0.67 \\
\hline $12-40$ & 0.063 & 3622 & 2585.1 & 2250.2 & 13.3 & 42.0 & 0.31 & 0.00 & 0.75 & 0.049 & 5196 & 2588.5 & 2168.8 & 13.0 & 41.8 & 0.29 & 0.00 & 0.75 \\
\hline Full Sample & 1.000 & 57867 & 579.1 & 576.4 & 8.1 & 34.3 & 0.43 & 0.16 & 0.45 & 1.000 & 106940 & 495.5 & 480.3 & 7.5 & 32.9 & 0.44 & 0.19 & 0.42 \\
\hline
\end{tabular}


Table 3 - Descriptive Statistics for Samples of Self-Employed Workers( $\left.{ }^{*}\right)$

\begin{tabular}{|c|c|c|c|c|c|c|c|c|c|c|c|c|c|c|c|c|c|c|}
\hline \multicolumn{4}{|c|}{ Sample: Status in Year2 } & \multicolumn{6}{|c|}{ Working as Self-Emploved } & \multicolumn{9}{|c|}{ Workinq, Unemploved or Inactive $\left({ }^{\star \star}\right)$} \\
\hline $\begin{array}{l}\text { Income / } \\
\text { Min. W. }\end{array}$ & $\begin{array}{l}\text { Sample } \\
\text { Fraction }\end{array}$ & N. Obs. & $\begin{array}{l}\text { Income } \\
\text { (Year 1) }\end{array}$ & $\begin{array}{l}\text { Income } \\
\text { (Year 2) }\end{array}$ & $\begin{array}{l}\text { Years of } \\
\text { School. }\end{array}$ & Age & $\begin{array}{c}\text { Women } \\
(\%)\end{array}$ & $\begin{array}{c}\text { Age }<21 \\
(\%)\end{array}$ & $\begin{array}{l}\text { Heads } \\
(\%)\end{array}$ & $\begin{array}{l}\text { Sample } \\
\text { Fraction }\end{array}$ & N. Obs. & $\begin{array}{l}\text { Income } \\
\text { (Year 1) }\end{array}$ & $\begin{array}{l}\text { Income } \\
\text { (Year 2) }\end{array}$ & $\begin{array}{l}\text { Years of } \\
\text { School. }\end{array}$ & Age & $\begin{array}{c}\text { Women } \\
(\%)\end{array}$ & $\begin{array}{c}\text { Age }<21 \\
(\%)\end{array}$ & $\begin{array}{c}\text { Heads } \\
(\%)\end{array}$ \\
\hline $0.5-0.9$ & 0.129 & 8020 & 102.8 & 154.5 & 3.6 & 40.1 & 0.63 & 0.05 & 0.43 & 0.151 & 14537 & 101.4 & 125.3 & 3.9 & 37.9 & 0.66 & 0.08 & 0.36 \\
\hline $0.9-1.1$ & 0.092 & 5702 & 140.3 & 204.2 & 4.1 & 40.5 & 0.49 & 0.03 & 0.53 & 0.099 & 9529 & 139.4 & 173.1 & 4.4 & 38.5 & 0.53 & 0.06 & 0.45 \\
\hline $1.1-1.5$ & 0.113 & 7021 & 196.2 & 249.7 & 4.0 & 40.3 & 0.43 & 0.03 & 0.58 & 0.120 & 11542 & 194.6 & 217.4 & 4.3 & 38.5 & 0.46 & 0.05 & 0.52 \\
\hline $1.5-2.0$ & 0.129 & 7986 & 252.7 & 302.6 & 4.5 & 40.6 & 0.35 & 0.02 & 0.65 & 0.126 & 12164 & 251.0 & 273.5 & 4.8 & 38.9 & 0.38 & 0.04 & 0.60 \\
\hline $2.0-2.5$ & 0.099 & 6166 & 334.3 & 366.2 & 4.8 & 40.4 & 0.29 & 0.02 & 0.71 & 0.095 & 9217 & 332.2 & 342.9 & 5.0 & 39.1 & 0.32 & 0.03 & 0.65 \\
\hline $2.5-3.0$ & 0.070 & 4377 & 376.1 & 401.9 & 5.1 & 40.5 & 0.25 & 0.01 & 0.73 & 0.065 & 6283 & 375.8 & 372.9 & 5.3 & 39.4 & 0.28 & 0.03 & 0.68 \\
\hline $3.0-3.5$ & 0.061 & 3776 & 445.8 & 459.5 & 5.4 & 40.4 & 0.23 & 0.01 & 0.75 & 0.056 & 5427 & 444.0 & 438.3 & 5.7 & 39.3 & 0.25 & 0.02 & 0.71 \\
\hline $3.5-4.0$ & 0.053 & 3272 & 547.2 & 514.1 & 5.5 & 40.7 & 0.21 & 0.01 & 0.77 & 0.049 & 4748 & 545.8 & 497.6 & 5.8 & 39.6 & 0.24 & 0.02 & 0.73 \\
\hline $4.0-5.0$ & 0.072 & 4448 & 638.7 & 595.6 & 6.2 & 40.6 & 0.20 & 0.01 & 0.78 & 0.065 & 6261 & 640.4 & 589.4 & 6.5 & 39.7 & 0.22 & 0.01 & 0.74 \\
\hline $5.0-6.0$ & 0.039 & 2416 & 703.8 & 668.3 & 6.7 & 40.7 & 0.19 & 0.01 & 0.79 & 0.036 & 3497 & 704.0 & 646.1 & 7.0 & 39.9 & 0.21 & 0.01 & 0.76 \\
\hline $6.0-9.0$ & 0.067 & 4164 & 996.4 & 837.6 & 7.6 & 40.7 & 0.18 & 0.01 & 0.80 & 0.063 & 6092 & 1004.0 & 835.0 & 7.9 & 39.9 & 0.20 & 0.01 & 0.77 \\
\hline $9.0-12$ & 0.032 & 1986 & 1311.3 & 1069.7 & 8.8 & 40.4 & 0.18 & 0.01 & 0.80 & 0.030 & 2898 & 1320.9 & 1090.2 & 9.1 & 39.8 & 0.20 & 0.01 & 0.76 \\
\hline $12-40$ & 0.045 & 2776 & 2450.0 & 1672.1 & 10.4 & 41.4 & 0.19 & 0.01 & 0.81 & 0.045 & 4368 & 2495.6 & 1727.2 & 10.8 & 40.8 & 0.19 & 0.00 & 0.80 \\
\hline Full Sample & 1.000 & 62110 & 487.8 & 459.3 & 5.3 & 40.5 & 0.34 & 0.02 & 0.66 & 1.000 & 96563 & 474.7 & 427.6 & 5.5 & 39.0 & 0.38 & 0.04 & 0.60 \\
\hline
\end{tabular}

(*) Sample means when not otherwise specified. $\left(^{* *}\right)$ The income of unemployed and out-of-the-labor-force individuals is assumed to be zero. Inactive individuals include those in school and homekeepers. 
Table 4 - Effects of Minimum Wages on Monthly Income of Registered Workers: Current and Lagged Percent Yearly Changes in Income for Different Ranges of Income Relative to the Minimum Wage (t-statistics are presented below their corresponding coefficients)

\begin{tabular}{|c|c|c|c|c|c|c|c|c|}
\hline \multirow{2}{*}{$\begin{array}{l}\text { Sample: Status } \\
\text { in Year } 2 \\
\text { Income Relative } \\
\text { to Minimum Wage: }\end{array}$} & \multicolumn{2}{|c|}{$\begin{array}{c}\text { Working as } \\
\text { Reqistered } \\
\text { Employee }\end{array}$} & \multicolumn{2}{|c|}{ Working } & \multicolumn{2}{|c|}{$\begin{array}{l}\text { Working or } \\
\text { Unemploved }\end{array}$} & \multicolumn{2}{|c|}{$\begin{array}{l}\text { Working, } \\
\text { Unemploved, } \\
\text { or Inactive }\end{array}$} \\
\hline & $\begin{array}{c}\text { Current } \\
{[1]}\end{array}$ & $\begin{array}{c}\text { Lagged } \\
{\left[1^{\prime}\right]}\end{array}$ & $\begin{array}{c}\text { Current } \\
{[2]}\end{array}$ & $\begin{array}{c}\text { Lagged } \\
{\left[2^{\prime}\right]}\end{array}$ & $\begin{array}{c}\text { Current } \\
{[3]}\end{array}$ & $\begin{array}{c}\text { Lagged } \\
{\left[3^{\prime}\right]}\end{array}$ & $\begin{array}{c}\text { Current } \\
{[4]}\end{array}$ & $\begin{array}{c}\text { Lagged } \\
{\left[4^{\prime}\right]}\end{array}$ \\
\hline \multirow[t]{2}{*}{$0.5-0.9$} & 1.43 & 0.03 & 1.40 & 0.05 & 1.35 & 0.08 & 1.21 & 0.09 \\
\hline & 15.42 & 0.44 & 15.87 & 0.84 & 15.15 & 1.29 & 13.98 & 1.44 \\
\hline \multirow[t]{2}{*}{$0.9-1.1$} & 1.08 & -0.17 & 1.08 & -0.15 & 1.06 & -0.12 & 0.98 & -0.13 \\
\hline & 36.75 & -7.97 & 37.88 & -7.43 & 36.63 & -5.69 & 34.05 & -5.99 \\
\hline \multirow[t]{2}{*}{$1.1-1.5$} & 0.89 & -0.07 & 0.90 & -0.05 & 0.88 & -0.02 & 0.82 & -0.04 \\
\hline & 29.08 & -3.11 & 30.54 & -2.40 & 29.27 & -0.80 & 27.49 & -1.70 \\
\hline \multirow[t]{2}{*}{$1.5-2.0$} & 0.83 & -0.06 & 0.82 & -0.06 & 0.78 & -0.04 & 0.74 & -0.05 \\
\hline & 30.73 & -2.71 & 31.15 & -2.71 & 29.36 & -1.92 & 27.77 & -2.55 \\
\hline \multirow[t]{2}{*}{$2.0-2.5$} & 0.71 & -0.07 & 0.70 & -0.06 & 0.68 & -0.056 & 0.66 & -0.05 \\
\hline & 24.11 & -2.93 & 24.15 & -2.75 & 23.02 & -2.48 & 22.13 & -2.18 \\
\hline \multirow[t]{2}{*}{$2.5-3.0$} & 0.63 & -0.15 & 0.61 & -0.15 & 0.59 & -0.14 & 0.58 & -0.15 \\
\hline & 18.14 & -5.45 & 17.90 & -5.52 & 16.87 & -5.13 & 16.24 & -5.19 \\
\hline \multirow[t]{2}{*}{$3.0-3.5$} & 0.62 & -0.15 & 0.58 & -0.14 & 0.58 & -0.11 & 0.58 & -0.12 \\
\hline & 17.10 & -5.12 & 16.22 & -5.02 & 15.99 & -3.92 & 15.58 & -3.92 \\
\hline \multirow[t]{2}{*}{$3.5-4.0$} & 0.56 & -0.11 & 0.54 & -0.11 & 0.53 & -0.10 & 0.55 & -0.08 \\
\hline & 14.31 & -3.57 & 14.02 & -3.76 & 13.36 & -3.27 & 13.73 & -2.73 \\
\hline \multirow[t]{2}{*}{$4.0-5.0$} & 0.52 & -0.11 & 0.52 & -0.10 & 0.51 & -0.09 & 0.52 & -0.08 \\
\hline & 16.00 & -4.21 & 16.10 & -3.80 & 15.48 & -3.33 & 15.53 & -3.08 \\
\hline \multirow[t]{2}{*}{$5.0-6.0$} & 0.46 & -0.19 & 0.44 & -0.18 & 0.46 & -0.15 & 0.47 & -0.14 \\
\hline & 10.88 & -5.18 & 10.58 & -5.13 & 10.57 & -4.21 & 10.66 & -3.78 \\
\hline \multirow[t]{2}{*}{$6.0-9.0$} & 0.49 & -0.16 & 0.48 & -0.17 & 0.49 & -0.14 & 0.51 & -0.13 \\
\hline & 15.56 & -6.49 & 15.46 & -6.71 & 15.36 & -5.57 & 15.61 & -5.17 \\
\hline \multirow[t]{2}{*}{$9.0-12$} & 0.42 & -0.20 & 0.40 & -0.21 & 0.42 & -0.19 & 0.43 & -0.18 \\
\hline & 9.40 & -5.24 & 9.06 & -5.62 & 9.10 & -5.00 & 9.25 & -4.49 \\
\hline \multirow[t]{2}{*}{$12-40$} & 0.39 & -0.24 & 0.38 & -0.24 & 0.40 & -0.22 & 0.43 & -0.21 \\
\hline & 11.28 & -8.78 & 11.13 & -8.69 & 11.24 & -7.82 & 11.95 & -7.20 \\
\hline Adjusted R2 & \multicolumn{2}{|c|}{0.16} & \multicolumn{2}{|c|}{0.15} & \multicolumn{2}{|c|}{0.13} & \multicolumn{2}{|c|}{0.11} \\
\hline $\mathrm{N}$ & \multicolumn{2}{|c|}{277280} & \multicolumn{2}{|c|}{313353} & \multicolumn{2}{|c|}{325378} & \multicolumn{2}{|c|}{337691} \\
\hline
\end{tabular}

Coefficient estimates correspond to the percent change in monthly income after a 1 percent increase in minimum wages. In all columns, the sample is restricted to registered individuals working for a wage in year 1. In [1] and [1'], the sample is restricted to individuals in this same status in year 2. In [2] to [4'], the sample also includes individuals that in year 2 are working as unregistered employees, self-employed or employers. In [3] to [4'] unemployed individuals in year 2 are also included, and in [4\} and [4'], individuals that are out of the labor force are added to the sample. 
Table 5 - Effects of Minimum Wages on Monthly Income of Un-Registered Workers: Current and Lagged Percent Yearly Changes in Income for Different Ranges of Income Relative to the Minimum Wage (t-statistics are presented below their corresponding coefficients)

\begin{tabular}{|c|c|c|c|c|c|c|c|c|}
\hline \multirow{2}{*}{$\begin{array}{l}\text { Sample: Status } \\
\text { in Year } 2 \\
\text { Income Relative } \\
\text { to Minimum Wage: }\end{array}$} & \multicolumn{2}{|c|}{$\begin{array}{l}\text { Working as } \\
\text { Un-Reqistered } \\
\text { Employee }\end{array}$} & \multicolumn{2}{|c|}{ Working } & \multicolumn{2}{|c|}{$\begin{array}{l}\text { Working or } \\
\text { Unemploved }\end{array}$} & \multicolumn{2}{|c|}{$\begin{array}{l}\text { Working, } \\
\text { Unemploved, } \\
\text { or Inactive }\end{array}$} \\
\hline & $\begin{array}{c}\text { Current } \\
{[1]}\end{array}$ & $\begin{array}{c}\text { Lagged } \\
{\left[1^{\prime}\right]}\end{array}$ & $\begin{array}{c}\text { Current } \\
{[2]}\end{array}$ & $\begin{array}{c}\text { Lagged } \\
{\left[2^{\prime}\right]}\end{array}$ & $\begin{array}{c}\text { Current } \\
{[3]}\end{array}$ & $\begin{array}{c}\text { Lagged } \\
{\left[3^{\prime}\right]}\end{array}$ & $\begin{array}{c}\text { Current } \\
{[4]}\end{array}$ & $\begin{array}{c}\text { Lagged } \\
{\left[4^{\prime}\right]}\end{array}$ \\
\hline \multirow[t]{2}{*}{$0.5-0.9$} & 1.18 & 0.09 & 1.39 & 0.21 & 1.32 & 0.20 & 1.00 & 0.07 \\
\hline & 16.35 & 1.72 & 21.28 & 4.31 & 20.33 & 4.21 & 16.19 & 1.49 \\
\hline \multirow[t]{2}{*}{$0.9-1.1$} & 1.03 & -0.10 & 1.12 & -0.04 & 1.06 & -0.02 & 0.84 & -0.08 \\
\hline & 15.61 & -1.98 & 20.04 & -1.06 & 19.06 & -0.51 & 15.47 & -2.06 \\
\hline \multirow[t]{2}{*}{$1.1-1.5$} & 0.82 & 0.03 & 0.79 & -0.03 & 0.70 & -0.04 & 0.66 & -0.03 \\
\hline & 11.27 & 0.44 & 12.74 & -0.68 & 11.30 & -0.91 & 10.77 & -0.63 \\
\hline \multirow[t]{2}{*}{$1.5-2.0$} & 0.64 & -0.20 & 0.68 & -0.13 & 0.62 & -0.14 & 0.56 & -0.13 \\
\hline & 8.70 & -3.35 & 10.74 & -2.49 & 9.63 & -2.75 & 8.77 & -2.38 \\
\hline \multirow[t]{2}{*}{$2.0-2.5$} & 0.66 & -0.10 & 0.73 & -0.09 & 0.65 & -0.092 & 0.64 & -0.05 \\
\hline & 7.90 & -1.49 & 10.04 & -1.63 & 8.84 & -1.63 & 8.56 & -0.95 \\
\hline \multirow[t]{2}{*}{$2.5-3.0$} & 0.46 & -0.26 & 0.49 & -0.30 & 0.46 & -0.28 & 0.43 & -0.25 \\
\hline & 4.80 & -3.53 & 5.57 & -4.32 & 5.14 & -3.94 & 4.71 & -3.44 \\
\hline \multirow[t]{2}{*}{$3.0-3.5$} & 0.50 & -0.20 & 0.55 & -0.17 & 0.56 & -0.15 & 0.56 & -0.12 \\
\hline & 5.19 & -2.69 & 6.06 & -2.40 & 6.06 & -2.08 & 5.96 & -1.58 \\
\hline \multirow[t]{2}{*}{$3.5-4.0$} & 0.42 & -0.25 & 0.46 & -0.23 & 0.46 & -0.21 & 0.50 & -0.19 \\
\hline & 4.36 & -3.48 & 5.01 & -3.32 & 4.89 & -2.88 & 5.17 & -2.54 \\
\hline \multirow[t]{2}{*}{$4.0-5.0$} & 0.42 & -0.19 & 0.47 & -0.21 & 0.47 & -0.18 & 0.53 & -0.14 \\
\hline & 5.09 & -2.88 & 5.85 & -3.38 & 5.84 & -2.83 & 6.29 & -2.10 \\
\hline \multirow[t]{2}{*}{$5.0-6.0$} & 0.24 & -0.32 & 0.32 & -0.26 & 0.31 & -0.25 & 0.37 & -0.20 \\
\hline & 2.38 & -3.78 & 3.13 & -3.13 & 2.97 & -2.92 & 3.44 & -2.31 \\
\hline \multirow[t]{2}{*}{$6.0-9.0$} & 0.28 & -0.28 & 0.34 & -0.26 & 0.34 & -0.25 & 0.40 & -0.22 \\
\hline & 3.72 & -4.67 & 4.54 & -4.48 & 4.40 & -4.20 & 5.05 & -3.50 \\
\hline \multirow[t]{2}{*}{$9.0-12$} & 0.37 & -0.06 & 0.43 & -0.09 & 0.43 & -0.07 & 0.50 & -0.01 \\
\hline & 3.35 & -0.67 & 4.12 & -0.95 & 4.02 & -0.80 & 4.45 & -0.12 \\
\hline \multirow[t]{2}{*}{$12-40$} & 0.24 & -0.31 & 0.28 & -0.31 & 0.28 & -0.28 & 0.37 & -0.23 \\
\hline & 2.74 & -4.29 & 3.20 & -4.38 & 3.21 & -3.97 & 4.04 & -3.07 \\
\hline Adjusted R2 & \multicolumn{2}{|c|}{0.16} & \multicolumn{2}{|c|}{0.18} & \multicolumn{2}{|c|}{0.15} & \multicolumn{2}{|c|}{0.12} \\
\hline $\mathrm{N}$ & \multicolumn{2}{|c|}{57867} & \multicolumn{2}{|c|}{95247} & \multicolumn{2}{|c|}{98683} & \multicolumn{2}{|c|}{106940} \\
\hline
\end{tabular}

Coefficient estimates correspond to the percent change in monthly income after a 1 percent increase in minimum wages. In all columns, the sample is restricted to un-registered individuals working for a wage in year $1 . \ln$ [1] and [1'], the sample is restricted to individuals in this same status in year 2. In [2] to [4'], the sample also includes individuals that in year 2 are working as registered employees, self-employed or employers. In [3] to [4'] unemployed individuals in year 2 are also included, and in [4\} and [4'], individuals that are out of the labor force are added to the sample. 
Table 6 - Effects of Minimum Wages on Monthly Income of Self-Employed Workers: Current and Lagged Percent Yearly Changes in Income for Different Ranges of Income Relative to the Minimum Wage (t-statistics are presented below their corresponding coefficients)

\begin{tabular}{|c|c|c|c|c|c|c|c|c|}
\hline \multirow{2}{*}{$\begin{array}{l}\text { Sample: Status } \\
\text { in Year } 2 \\
\text { Income Relative } \\
\text { to Minimum Wage: }\end{array}$} & \multicolumn{2}{|c|}{$\begin{array}{l}\text { Working as } \\
\text { Self-Emploved }\end{array}$} & \multicolumn{2}{|c|}{ Working } & \multicolumn{2}{|c|}{$\begin{array}{l}\text { Working or } \\
\text { Unemploved }\end{array}$} & \multicolumn{2}{|c|}{$\begin{array}{l}\text { Working, } \\
\text { Unemploved, } \\
\text { or Inactive }\end{array}$} \\
\hline & $\begin{array}{c}\text { Current } \\
{[1]} \\
\end{array}$ & $\begin{array}{c}\text { Lagged } \\
{\left[1^{\prime}\right]}\end{array}$ & $\begin{array}{c}\text { Current } \\
{[2]}\end{array}$ & $\begin{array}{c}\text { Lagged } \\
{\left[2^{\prime}\right]} \\
\end{array}$ & $\begin{array}{c}\text { Current } \\
{[3]}\end{array}$ & $\begin{array}{c}\text { Lagged } \\
{\left[3^{\prime}\right]} \\
\end{array}$ & $\begin{array}{c}\text { Current } \\
{[4]}\end{array}$ & $\begin{array}{c}\text { Lagged } \\
{\left[4^{\prime}\right]}\end{array}$ \\
\hline \multirow[t]{2}{*}{$0.5-0.9$} & 1.18 & 0.26 & 1.21 & 0.19 & 1.13 & 0.21 & 0.82 & 0.15 \\
\hline & 13.45 & 3.87 & 15.56 & 3.33 & 14.58 & 3.67 & 11.73 & 2.82 \\
\hline \multirow[t]{2}{*}{$0.9-1.1$} & 1.32 & 0.34 & 1.31 & 0.25 & 1.24 & 0.24 & 0.98 & 0.15 \\
\hline & 12.90 & 4.28 & 14.45 & 3.63 & 13.78 & 3.44 & 11.61 & 2.35 \\
\hline \multirow[t]{2}{*}{$1.1-1.5$} & 0.77 & 0.11 & 0.89 & 0.06 & 0.86 & 0.06 & 0.75 & 0.05 \\
\hline & 8.60 & 1.66 & 11.49 & 1.08 & 11.16 & 0.99 & 10.14 & 0.85 \\
\hline \multirow[t]{2}{*}{$1.5-2.0$} & 0.63 & 0.08 & 0.63 & 0.01 & 0.60 & 0.01 & 0.54 & 0.00 \\
\hline & 7.41 & 1.07 & 8.39 & 0.21 & 7.89 & 0.22 & 7.39 & 0.04 \\
\hline \multirow[t]{2}{*}{$2.0-2.5$} & 0.59 & 0.16 & 0.66 & 0.13 & 0.65 & 0.161 & 0.65 & 0.17 \\
\hline & 6.01 & 2.13 & 7.65 & 2.01 & 7.52 & 2.42 & 7.66 & 2.56 \\
\hline \multirow[t]{2}{*}{$2.5-3.0$} & 0.33 & -0.05 & 0.44 & -0.03 & 0.44 & -0.01 & 0.51 & 0.04 \\
\hline & 2.71 & -0.48 & 4.02 & -0.38 & 4.01 & -0.15 & 4.64 & 0.48 \\
\hline \multirow[t]{2}{*}{$3.0-3.5$} & 0.38 & -0.11 & 0.43 & -0.14 & 0.43 & -0.10 & 0.45 & -0.07 \\
\hline & 2.80 & -0.98 & 3.59 & -1.45 & 3.55 & -1.07 & 3.72 & -0.74 \\
\hline \multirow[t]{2}{*}{$3.5-4.0$} & 0.48 & 0.11 & 0.48 & 0.10 & 0.47 & 0.11 & 0.50 & 0.10 \\
\hline & 3.94 & 1.09 & 4.41 & 1.15 & 4.25 & 1.30 & 4.58 & 1.18 \\
\hline \multirow[t]{2}{*}{$4.0-5.0$} & 0.65 & 0.11 & 0.71 & 0.12 & 0.71 & 0.14 & 0.75 & 0.17 \\
\hline & 5.79 & 1.26 & 7.11 & 1.54 & 7.05 & 1.74 & 7.46 & 2.08 \\
\hline \multirow[t]{2}{*}{$5.0-6.0$} & 0.13 & -0.11 & 0.10 & -0.20 & 0.09 & -0.19 & 0.14 & -0.13 \\
\hline & 0.83 & -0.80 & 0.71 & -1.64 & 0.64 & -1.56 & 0.98 & -1.10 \\
\hline \multirow[t]{2}{*}{$6.0-9.0$} & 0.38 & 0.03 & 0.36 & 0.01 & 0.39 & 0.03 & 0.43 & 0.04 \\
\hline & 3.40 & 0.37 & 3.75 & 0.09 & 3.93 & 0.34 & 4.39 & 0.51 \\
\hline \multirow[t]{2}{*}{$9.0-12$} & 0.12 & -0.08 & 0.21 & -0.09 & 0.21 & -0.09 & 0.23 & -0.09 \\
\hline & 0.74 & -0.58 & 1.59 & -0.80 & 1.57 & -0.74 & 1.69 & -0.77 \\
\hline \multirow[t]{2}{*}{$12-40$} & 0.22 & -0.06 & 0.23 & -0.14 & 0.25 & -0.11 & 0.33 & -0.07 \\
\hline & 1.69 & -0.59 & 2.09 & -1.55 & 2.25 & -1.22 & 2.90 & -0.72 \\
\hline Adjusted R2 & \multicolumn{2}{|c|}{0.16} & \multicolumn{2}{|c|}{0.18} & \multicolumn{2}{|c|}{0.16} & \multicolumn{2}{|c|}{0.13} \\
\hline $\mathrm{N}$ & \multicolumn{2}{|c|}{62110} & \multicolumn{2}{|c|}{85101} & \multicolumn{2}{|c|}{86939} & \multicolumn{2}{|c|}{96563} \\
\hline
\end{tabular}

Coefficient estimates correspond to the percent change in monthly income after a 1 percent increase in minimum wages. In all columns, the sample is restricted to self-employed working for a wage in year 1. In [1] and [1'], the sample is restricted to individuals in this same status in year 2. In [2] to [4'], the sample also includes individuals that in year 2 are working as registered and unregistered employees, or employers. In [3] to [4'] unemployed individuals in year 2 are also included, and in [4\} and [4'], individuals that are out of the labor force are added to the sample. 


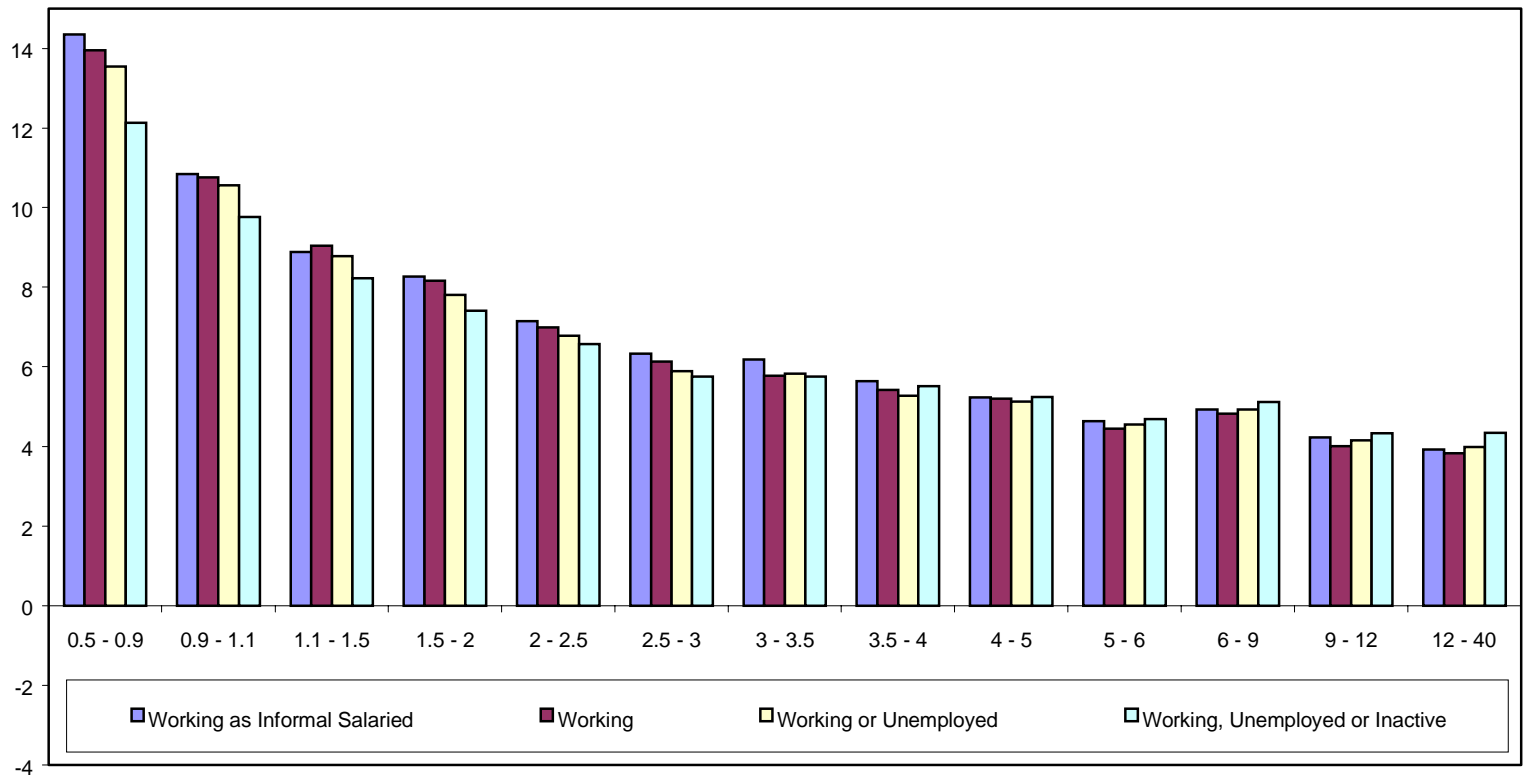

Figure 1 - First Year Income Effects of a 10\% Increase in Minimun Wages: Registered Workers

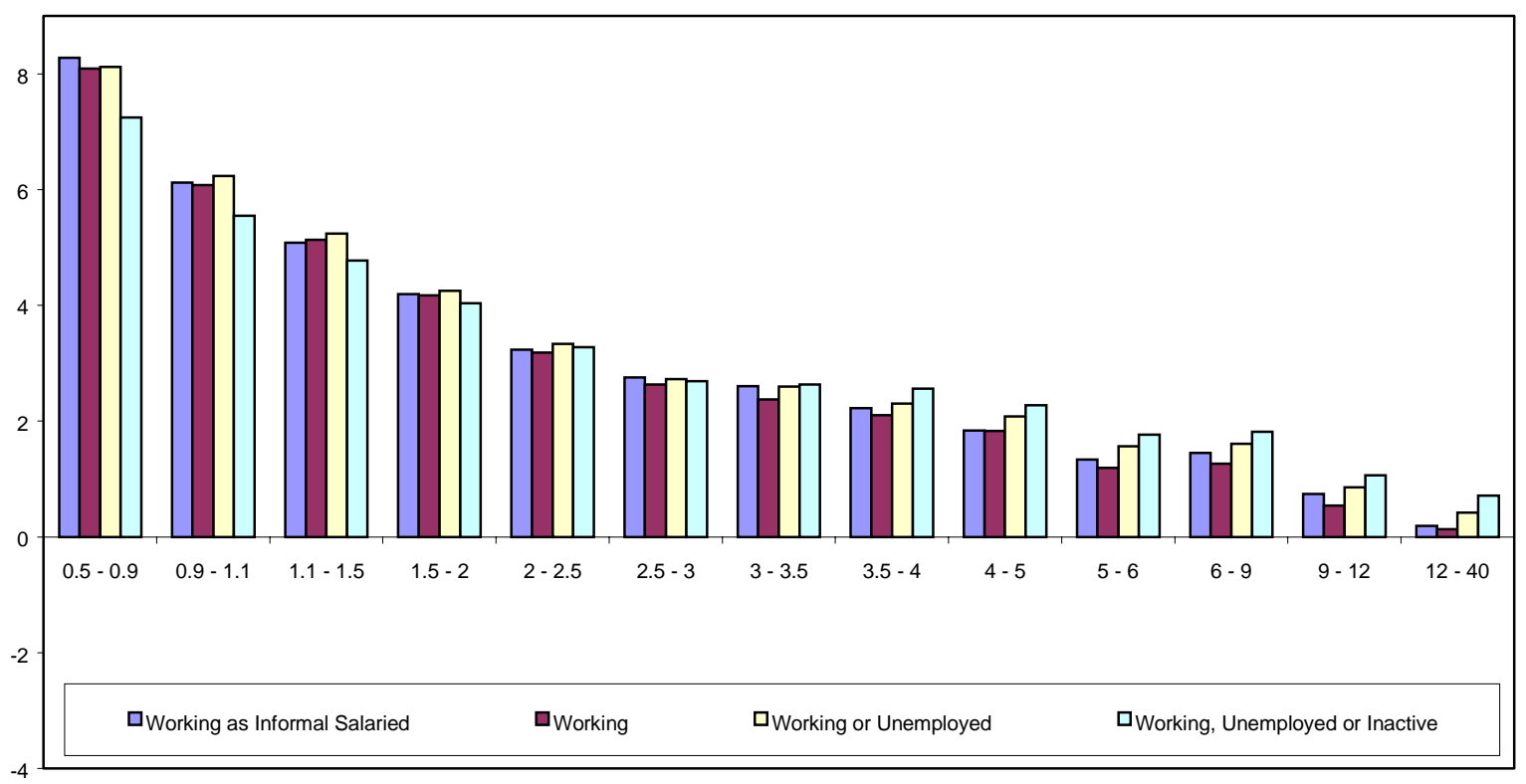

Figure 2 - Second Year Income Effects of a 10\% Increase in Minimun Wages: Registered Workers 


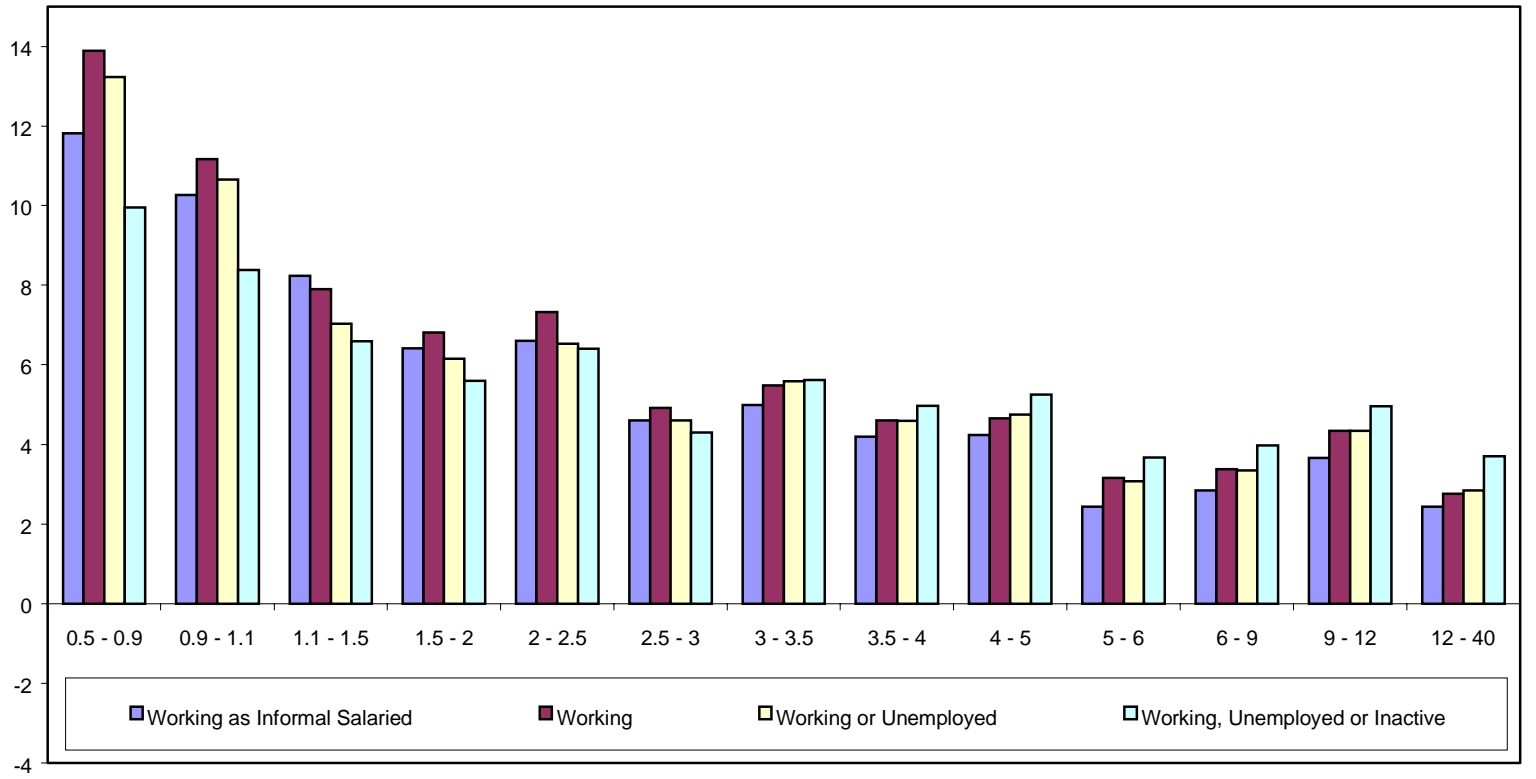

Figure 3 - First Year Income Effects of a 10\% Increase in Minimun Wages: Un-Registered Workers

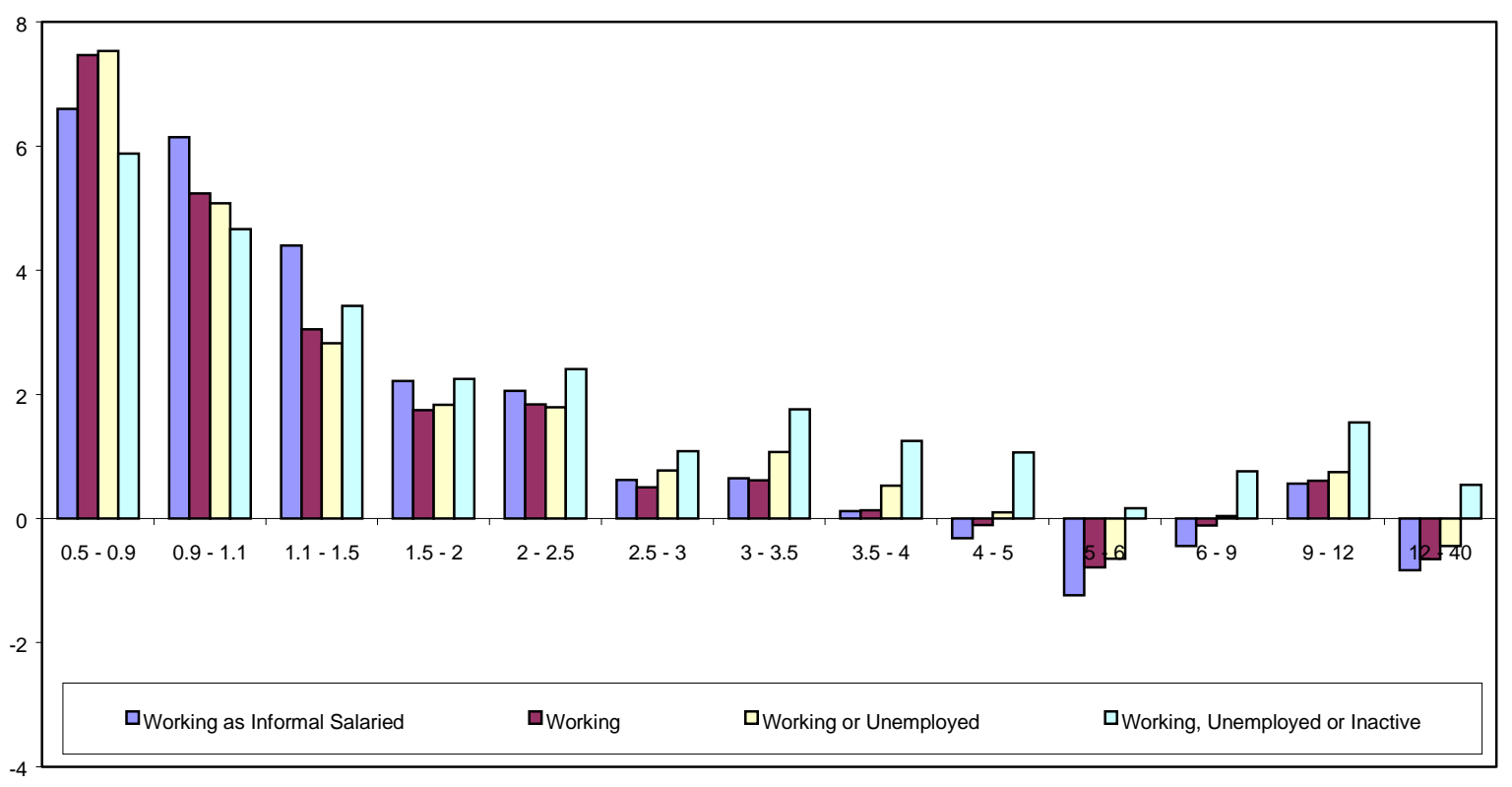

Figure 4 - Second Year Income Effects of a 10\% Increase in Minimun Wages: Un-Registered Workers 